\title{
Studi Laju Dekomposisi Serasah Pada Hutan Pinus di Kawasan Wisata Taman Safari Indonesia II Jawa Timur
}

\author{
Ory Kurnia Ayu Devianti dan Indah Trisnawati Dwi Tjahjaningrum \\ Departemen Biologi, Fakultas Ilmu Alam, Institut Teknologi Sepuluh Nopember (ITS) \\ e-mail:trisnawati@biologi.its.ac.id
}

\begin{abstract}
Abstrak-Dekomposisi serasah merupakan proses yang sangat penting dalam dinamika hara pada suatu ekosistem. Tujuan dari penelitian ini adalah untuk mengetahui laju dekomposisi serasah pada hutan pinus di kawasan Wisata Taman Safari Indonesia II, Prigen Jawa Timur. Penanaman sampel serasah menggunakan Litterbag berdasarkan kecenderungan curah hujan. Periode I curah hujan cenderung tinggi dan Periode II cenderung rendah. Faktor lingkungan yang diukur meliputi faktor abiotik (suhu tanah, curah hujan) dan faktor kimia (kandungan lignin). Analisa data dengan uji statistik yaitu korelasi Pearson. Laju dekomposisi tertinggi terjadi pada periode I dengan kondisi curah hujan yang cenderung tinggi dibandingkan dengan periode II yang curah hujannya cenderung rendah. Berdasarkan uji yang telah dilakukan dapat disimpulkan bahwa laju dekomposisi serasah pada hutan dominan pinus lebih dipengaruhi curah hujan $(p=0.749)$ dibandingkan dengan suhu $(p=0.506)$ dan kandungan lignin.
\end{abstract}

Kata Kunci-laju dekomposisi, Pinus, Serasah, Taman Safari Indonesia II, vegetasi.

\section{PENDAHULUAN}

D EKOMPOSISI serasah merupakan proses yang sangat penting dalam dinamika hara pada suatu ekosistem. Dekomposisi serasah merupakan langkah penting dalam siklus hara dan dapat memberikan nutrisi untuk tanaman. Setiap ekosistem memiliki kondisi fisik dan lingkungan tertentu yang menyebabkan terjadinya perbedaan komposisi spesiesnya. Setiap jenis pohon mempengaruhi laju dekomposisi serasah yang berbeda karena kualitas serasah yang berbeda dan berkaitan erat dengan komunitas mikroba tanah dan siklus hara tanah [1]. Proses tersebut sangat vital untuk keberlanjutan status hara pada tanaman hutan dan kecepatan dekomposisinya bervariasi untuk spesies tanaman yang berbeda.

Dekomposisi merupakan proses perubahan secara fisik maupun secara kimiawi yang sederhana oleh mikroorganisme tanah, dan terkadang disebut mineralisasi. Dekomposisi merupakan proses yang dinamis dan sangat dipengaruhi oleh keberadaan dekomposer baik jumlah maupun diversitasnya. Laju dekomposisi serasah dipengaruhi oleh faktor lingkungan, contoh pH; iklim (temperatur, kelembaban); komposisi kimia dari serasah dan mikroorganisme tanah. Beberapa penelitian melaporkan bahwa beberapa sifat kimia seperti kandungan awal lignin, selulosa dan karbohidrat berpengaruh secara nyata terhadap tingkat dekomposisi serasah daun. Tingkat dekomposisi serasah daun dilaporkan berhubungan dengan kandungan awal lignin dan selulosa [2], dan kandungan awal nitrogen [3]. Berdasarkan [4] bahwa tingkat dekomposisi beberapa jenis daun tanaman hutan dipengaruhi oleh kandungan awal selulosa, lignin, karobohidrat, karbon (C), nitrogen $(\mathrm{N})$ dan nisbah $\mathrm{C} / \mathrm{N}$. Proses dekomposisi dimulai dari proses penghancuran yang dilakukan oleh serangga kecil terhadap tumbuhan dan sisa bahan organik mati menjadi ukuran yang lebih kecil.

Berdasarkan penelitian [5], laju dekomposisi serasah pada hutan tropis lebih cepat dibandingkan di hutan subtropis. Selain itu di hutan tropis ataupun subtropis lebih cepat terdekomposisi pada serasah yang campuran (terdiri dari 10 spesies serasah) dibandingkan dengan serasah yang hanya satu spesies tanaman saja. Selain itu, hutan di Atlantik dan Restinga memiliki kecepatan laju dekomposisi dua kali lebih cepat dibandingkan dengan hutan semi-deciduous dan Cerradao. Hal ini disebabkan karena perbedaan iklim antara keempat tempat tersebut. Iklim merupakan faktor utama yang mempengaruhi laju dekomposisi, karena merupakan regulator utama bakteri dan metabolisme jamur.

Dari berbagai penelitian laju dekomposisi serasah di atas, masih sedikit penelitian yang mengaitkan suhu, curah hujan terhadap laju dekomposisi serasah pada hutan Pinus. Selain itu penelitian laju dekomposisi di hutan wisata Taman Safari Indonesia II, Prigen juga belum pernah dilakukan sebelumnya. Hutan di area kawasan wisata Taman Safari Indonesia II belum dilakukan pengelolaan lebih lanjut oleh pihak TSI II sehingga hutan masih bisa dianggap hutan yang alami. Penelitian ini dilakukan pada tipe hutan Pinus dengan tujuan mengetahui laju dekomposisi pada hutan dominan Pinus. Oleh karena itu, hal tersebut mendasari peneliti untuk melakukan penelitian yang bertujuan mengetahui laju dekomposisi serasah di kawasan Hutan Wisata Taman Safari Indonesia II, Prigen, Jawa Timur, mengingat pentingnya proses dekomposisi atau mineralisasi dalam siklus hara tanah.

\section{METODE PENELITIAN}

\section{A. Waktu dan Tempat}

Penelitian ini dilakukan dari bulan Maret 2016-Juli 2017 pada beberapa tipe hutan yang berbeda di hutan wisata Taman Safari Indonesia II, Prigen, Jawa Timur. Analisis data dan kandungan lignin dilakukan di laboratorium Ekologi, Departemen Biologi, Fakultas Matematika dan Ilmu Pengetahuan Alam. 


\section{B. Alat dan Bahan}

Alat dan bahan yang digunakan dalam penelitian ini terdiri dari box sampel, sekop atau linggis, termometer, meteran lapangan, meteran jahit, Global Positioning System (GPS), plastik besar, kertas label, kamera, Alluminium foil, oven, timbangan digital, alat tulis menulis.

\section{Pengukuran Faktor Lingkungan dan Kimia}

\section{1) Suhu}

Pengukuran suhu tanah menggunakan Soil Survey Instrumen. Sebelum digunakan Soil Survey Instrumen dipastikan dalam kondisi "on" terlebih dahulu. Kemudian Soil Survey Instrumen bagian ujungnya dimasukkan ke dalam tanah dengan secara tegak lurus. Kemudian untuk mengetahui faktor lingkungan lainnya dengan menekan tombol switch di bagian kiri dari alat Soil Survey Instrumen.

2) Curah Hujan

Data curah hujan didapatkan dari Stasiun Geofisika Kelas II Tretes Jawa Timur

\section{3) Kandungan Lignin}

Pengukuran kandungan lignin pada serasah di lakukan di Laboratorium Jurusan Ekologi, Departemen Biologi, Fakultas Matematika dan Ilmu Pengetahuan Alam Institut Teknologi Sepuluh Nopember.

Analisis selulosa dan lignin dilakukan dengan metode Chesson [6]. Satu g (a) sampel kering ditambahkan $150 \mathrm{ml}$ $\mathrm{H}_{2} \mathrm{O}$. Direfluk pada suhu $100^{\circ} \mathrm{C}$ dengan waterbath selama 1 jam. Hasilnya disaring, residu dicuci dengan air panas (300 $\mathrm{mL}$ ). Residu kemudian dikeringkan dengan oven sampai konstan kemudian ditimbang (b). Residu ditambahkan $150 \mathrm{~mL}$ $\mathrm{H}_{2} \mathrm{SO}_{4} 1 \mathrm{~N}$ kemudian direfluk dengan waterbath selama 1 jam suhu $100^{\circ} \mathrm{C}$. Hasilnya disaring sampai netral $(300 \mathrm{~mL})$ dan dikeringkan (c). Residu kering ditambahkan $10 \mathrm{~mL} \mathrm{H}_{2} \mathrm{SO}_{4}$ $72 \%$ dan direndam pada suhu kamar selama 4 jam. Ditambahkan $150 \mathrm{~mL} \mathrm{H}_{2} \mathrm{SO}_{4} 1 \mathrm{~N}$ dan direfluk pada water bath selama 1 jam pada pendingin balik. Residu disaring dan dicuci dengan $\mathrm{H}_{2} \mathrm{O}$ sampai netral $(400 \mathrm{ml})$ kemudian dipanaskan dengan oven dengan suhu $105^{\circ} \mathrm{C}$ dan hasilnya ditimbang (d), selanjutnya residu diabukan dan ditimbang (e) [6].

Perhitungan kadar selulosa:

$$
\text { Kadar selulosa }=\frac{c-d}{a} \times 100 \%
$$

Perhitungan kadar lignin:

$$
\text { Kadar lignin }=\frac{d-e}{a} \times 100 \%
$$

\section{Perlakuan Serasah}

\section{1) Pengumpulan Serasah}

Pengumpulan sampel serasah diambil di lantai hutan paling atas di masing-masing hutan. Pengambilan sampel serasah dilakukan secara acak tanpa dilakukan pemilahan terlebih dahulu.

\section{2) Penanaman Serasah}

Penanaman serasah ini dilakukan dengan cara memasukkan serasah hasil pengumpulan ke dalam kantong jaring yang ditempatkan di lantai hutan (hal ini dimaksudkan agar terjadi proses dekomposisi sealami mungkin). Penanaman serasah ini menggunakan metode litterbag. Metode litterbag digunakan untuk penelitian dekomposisi ini. Litterbag dibentuk seperti kantong plastik yang dijahit bagian bawah dan samping.
Sedangkan bagian atasnya digunakan untuk memasukkan serasah. Serasah yang diambil di lantai hutan ditimbang sekitar 125 gram. Kemudian serasah dimasukkan ke dalam litterbag dan dijahit bagian atasnya. Setelah itu litterbag ditanam pada masing-masing plot yang sudah ditentukan dengan kedalaman $0,5 \mathrm{~m}$. Litterbag yang telah ditanam dibiarkan selama 30, 60, dan 90 hari pada bulan pertama yang dianggap curah hujan yang tinggi dan penanaman dimulai pada bulan Maret 2016 dan terakhir panen pada bulan Juli 2016. Pada bulan Juli 2016 dilakukan penanaman lagi untuk bulan kedua yang dianggap sebagai curah hujan yang rendah, dan terakhir panen pada bulan September 2016. Litterbag yang ditanam di masing-masing hutan berjumlah 3 plot, dengan masing-masing plot terdiri dari 3 litterbag yang ditanam.

Litterbag yang telah diambil dari masing-masing plot dicuci dengan hati-hati terlebih dahulu sebelum dioven. Pencucian serasah ini bertujuan untuk memisahkan serangga dan tanah dari serasahnya [7]. Kemudian seresah dikering angin dan dibungkus dengan aluminium foil. Setelah itu dioven selama 48 jam dengan suhu $80^{\circ} \mathrm{C}$ [1]. Kemudian ditimbang berat kering dari serasah yang telah dioven.

\section{E. Analisis Data}

1) Analisis Kuantitatif Laju Dekomposisi Serasah

Untuk menghitung laju dekomposisi serasah, dilakukan perhitungan berat kering serasah terlebih dahulu yang dapat dilihat hasil perhitungannya pada Lampiran I. Kemudian dilakukan perhitungan berkurangnya berat serasah dengan cara yang sama dengan dilakukan oleh:

$$
L(\%)=\frac{100(W o-W t)}{W o}
$$

Dimana

$L \quad$ : hilangnya berat serasah

Wo : berat serasah sebelum penelitian dimulai

$W t$ : berat kering serasah yang tertinggal setelah waktu $t$ time

Laju dekomposisi serasah dihitung menggunakan rumus sesuai dengan [8]:

$$
R=\frac{\mathrm{W} 0-\mathrm{Wt}}{\mathrm{T}}
$$

Dimana

$\mathrm{R}$ : laju dekomposisi (g/ minggu)

$\mathrm{T}$ : waktu pengamatan (minggu)

Wo : berat kering awal dari serasah

Wt : berat kering akhir serasah $(\mathrm{g})$ per periode waktu $\mathrm{t}$

\section{2) Analisis Pengaruh Suhu, Curah Hujan Dan Kandungan} Lignin Terhadap Laju Dekomposisi Serasah

Data iklim berupa curah hujan dari Badan Meteorologi dan Geofisika (BMKG) setempat (stasiun Klimatologi Prigen) dipergunakan untuk mengetahui pengaruhnya terhadap kecepatan laju dekomposisi serasah di setiap lokasi. Dalam hal ini pengujiannya dilakukan dengan menggunakan uji korelasi Pearson untuk mengetahui hubungan antara setiap faktor (curah hujan dan suhu) dengan laju dekomposisi serasah. Uji dilakukan dengan taraf kepercayaan 95\% $(p<0.05)$. 


\section{HASIL DAN DISKUSI}

\section{A. Hasil Pengukuran Parameter Lingkungan}

Parameter lingkungan yang diambil dilapangan serta yang diuji di Laboratorium meliputi faktor fisika dan kimia yaitu suhu tanah dan kelembaban yang diambil secara langsung di lapangan, curah hujan didapatkan data dari Badan Meteorologi Klimatologi dan Geofisika Tretes. Hasil pengukuran parameter lingkungan di titik sampling selama pengamatan, disajikan dalam Tabel 1 dan Gambar 1.

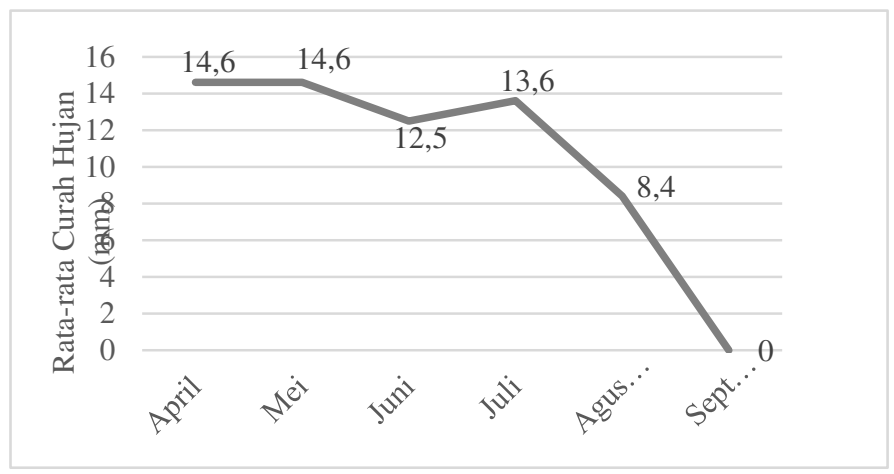

Gambar. 1. Grafik rata-rata curah hujan di Prigen, Pasuruan, Jawa Timur periode bulan April - September.

Tabel 1.

Hasil Pengukuran Faktor Lingkungan di Hutan Dominan Pinus

\begin{tabular}{lrrrrrr} 
& April & Mei & Juni & Juli & Agt & Sept \\
\hline Suhu & & & & & & \\
\hline \hline
\end{tabular}

Tabel 2.

Hasil Pengukuran Kandungan Lignin Pada Serasah di Hutan Dominan Pinus

\begin{tabular}{cc}
\hline \hline Parameter & Serasah Dominan Pinus \\
\hline Kandungan Lignin (\%) & 3.65 \\
\hline \hline
\end{tabular}

Berdasarkan kedua tabel di atas hasil data parameter lingkungan baik yang diukur langsung di lapangan dan yang dianalisis di laboratorium pada hutan dominan Pinus.

Parameter curah hujan, didapatkan data area Prigen, Pasuruan memiliki volume curah hujan cenderung tinggi pada bulan April dan Mei sebesar $14.6 \mathrm{~mm}$, dan curah hujan cenderung rendah terjadi pada bulan September sebesar $0 \mathrm{~mm}$. Menurut [8] curah hujan yang tinggi akan menyebabkan tanah-tanah yang tidak tertutupi oleh vegetasi rentan sekali terhadap pencucian yang akan mengurang kesuburan tanah dengan cepat. Curah hujan juga mempengaruhi berbagai aktivitas biologi karena berpengaruh terhadap kelembaban tanah dan suhu. Curah hujan dapat mengendalikan proses pencucian serasah secara fisik, dengan curah hujan yang tinggi dapat mempercepat pemecahan serasah [9].

Hasil pengukuran lingkungan yang diambil secara langsung di lapangan pada ketiga titik sampling didapatkan data dimana parameter suhu tanah $\left({ }^{\circ} \mathrm{C}\right)$, pada periode I suhu rata-rata pada hutan dominan Pinus sebesar $24.83{ }^{\circ} \mathrm{C}$ dan periode II rata-rata $23.67{ }^{\circ} \mathrm{C}$.

Lignin merupakan salah satu polimer fenilpropanoid yang sulit dirombak, oleh karena strukturnya heterogen dan sangat kompleks. Lebih dari $30 \%$ material tumbuhan tersusun oleh lignin, sehingga dapat memberikan kekuatan pada kayu terhadap serangan mikroorganisme [10]. Sedangkan kandungan lignin pada hutan dominan Pinus sebesar 3.65\%.

Hasil perhitungan laju dekomposisi serasah menunjukkan hasil yang berbeda-beda baik pada setiap minggunya. Berikut grafik laju dekomposisi serasah pada hutan dominan Pinus pada setiap periode pengambilan sampel.

Laju Dekomposisi Serasah pada Hutan Dominan Pinus

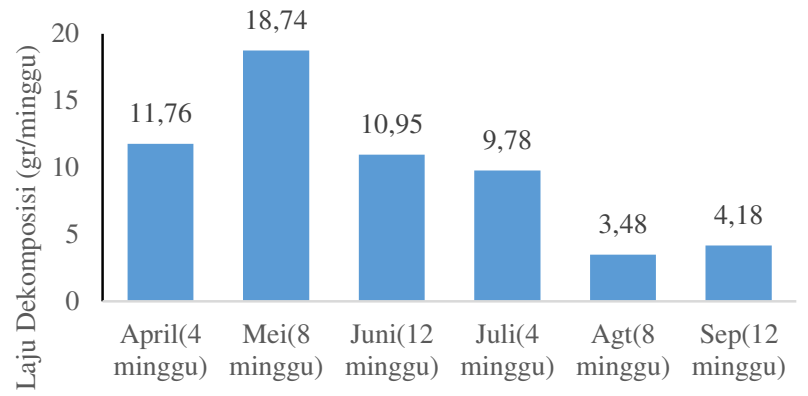

Gambar 2 Grafik Laju Dekomposisi Serasah Pinus pada Kedua Periode Pengambilan Sampel

Laju dekomposisi serasah Pinus merkusii dapat dihitung dari perubahan bobot kering serasah selama proses dekomposisi [11]. Kehilangan bobot yang cepat disebabkan karena bahan organik yang dimanfaatkan oleh mikroorganisme untuk memperoleh energi dan penyusun sel mikroorganisme. Kehilangan bobot semakin lambat disebabkan karena sumber karbon dari bahan organik yang semakin berkurang [12].

Gambar 2 menunjukkan laju dekomposisi serasah pada pengambilan sampel periode I (April-Juni). Periode I dan II menunjukkan kecenderungan volume curah hujan yang tinggi. Berdasarkan gambar 2 dapat dilihat bahwa kecepatan laju dekomposisi serasah pada setiap lokasi pengamatan cenderung menurun setiap bulannya. Laju dekomposisi yang tinggi pada bulan April-Juni cenderung tinggi dibandingkan dengan periode II (Juli-September). Hal ini juga didukung oleh penelitian [13], bahwa laju dekomposisi serasah Acacia mangium dan Pinus merkusii di Hutan Gunung Walat, Sukabumi, berkorelasi positif dengan besarnya curah hujan. Menurut [14] bahwa perubahan frekuensi dan distribusi curah hujan dapat mempengaruhi dekomposisi serasah. Curah hujan dapat mengendalikan proses pencucian serasah secara fisik, dengan curah hujan yang tinggi dapat mempercepat pemecahan serasah [9]. Selain itu curah hujan juga mempengaruhi kelembaban dan suhu tanah sehingga dapat mempengaruhi aktivitas biologi dalam mendekomposisi serasah. Sedangkan pada pengambilan sampel periode II (Juli, Agustus, September) (Gambar 2) dianggap sebagai periode dimana curah hujan yang cenderung rendah, dibandingkan bulan April, Mei dan Juni. Laju dekomposisi serasah pada periode II ini lebih rendah dibandingkan dengan periode I.

Hasil laju dekomposisi serasah dapat dilihat bahwa setiap pengambilan kantong serasah pertama memiliki nilai laju dekomposisi yang tinggi, kemudian menurun pada bulanbulan berikutnya. Hal ini terjadi pada ketiga titik lokasi penanaman kantong. Selama proses dekomposisi, laju dekomposisi setiap pelakuan lama kelamaan mengalami 
penurunan sampai pada akhir pengomposan. Penguraian serasah daun disetiap minggunya berbeda dimana pada awalnya nilai laju dekomposisi akan tinggi dan kemudian menurun, yang berarti pada awalnya serasah terurai dengan cepat dan kemudain semakin lambat dengan semakin lamanya periode waktu serasah terdekomposisi. Hal ini disebabkan karena bahan organik yang tersedia semakin lama semakin sedikit yang disebabkan oleh aktivitas mikroba yang mengurai sampah organik. Hal ini dikarenakan pada serasah yang masih baru masih banyak persediaan unsur-unsur yang merupakan makanan bagi mikroba tanah atau bagi bagi organisme pengurai, sehingga serasah cepat hancur. Unsur tersebut semakin berkurang yang berarti penghancuranya juga lambat sampai hanya tinggal unsur yang tidak diperlukan oleh dekomposer. Selain itu kadar air yang terdapat pada serasah yang masih baru akan mudah menguap sehingga berat kering serasah pada awal minggu mengalami penurunan yang tinggi yang juga membuat laju dekomposisinya menjadi cepat. Sebagai proses yang dinamis, dekomposisi memiliki dimensi kecepatan yang mungkin berbeda dari waktu ke waktu tergantung faktor yang mempengaruhi pertumbuhan dekomposer disamping faktor bahan yang akan di dekomposisi [15]. Proses dekomposisi bahan organik secara alami akan berhenti bila faktor-faktor pembatasnya tidak tersedia atau telah dihabiskan dalam proses dekomposisi itu sendiri. Selama proses dekomposisi akan terjadi penyusutan volume bahan. Pengurangan ini mencapai $30-40 \%$ dari volume awal bahan [16].

Laju dekomposisi yang cenderung tinggi pada periode I terjadi pada hutan dominan Pinus dengan rata-rata laju dekomposisi tiap minggu sebesar 10.95 gr/minggu sedangkan periode sangat rendah yaitu $4.18 \mathrm{gr} / \mathrm{minggu}$. Hal ini dikarenakan pada hutan dominan Pinus pada periode I memiliki suhu tanah yang tinggi dengan masing-masing sebesar $24.83{ }^{\circ} \mathrm{C}$ dibandingkan dengan periode II. Area penanaman serasah yang memiliki suhu yang lebih tinggi, maka bahan organik akan mengurai lebih cepat (apabila kelembaban yang memadai juga tersedia). Lingkungan yang panas dan lembab dapat mendorong tingkat aktivitas mikroba yang tinggi. Dimana aktivitas fauna dan mikroorganisme meningkat, seiring dengan peningkatan suhu tanah. Faktor iklim terutama suhu dan kelembaban tanah (dipengaruhi oleh curah hujan) sangat menentukan keragaman fungsional organisme tanah. Secara keseluruhan iklim akan mempengaruhi fisiologi organisme tanah, misalnya aktivitas dan pertumbuhan fauna akan meningkat ketika suhu dan kelembaban meningkat. Jika pasokan hara untuk tanaman berhenti, bahan organik yang ada dapat terurai dengan cepat [17]. Temperatur udara yang optimal akan berpengaruh pada dekomposisi serasah secara tidak langsung. Hal ini menyebabkan serasah menjadi terdekomposisi lebih sempurna. Hal ini didukung dengan penelitian [18] bahwa suhu memberikan pengaruh yang signifikan pada penurunan massa serasah. Suhu yang tinggi $\left(24{ }^{\circ} \mathrm{C}\right.$ dan $\left.30{ }^{\circ} \mathrm{C}\right)$ menyebabkan penurunan berat pada Pinus patula lebih besar dibandingkan dengan suhu $\left(15^{\circ} \mathrm{C}\right.$ dan $\left.18^{\circ} \mathrm{C}\right)$, sehingga laju dekomposisinya juga tinggi. Penurunan berat serasah ini karena suhu mempengaruhi aktivitas mikroba [18].

Selain itu, kualitas serasah juga merupakan faktor penting dalam laju dekomposisi serasah. Kandungan lignin pada serasah juga dapat mempengaruhi kecepatan laju dekomposisi. Lignin memiliki peran penting dalam proses dekomposisi serasah dan juga beberapa proses ekologi. Beberapa peneliti mengatakan bahwa lignin dapat dijadikan prediktor laju dekomposisi serasah. Konsentrasi lignin lebih berpengaruh dibandingkan konsentrasi kimia lainnya dalam menentukan laju dekomposisi serasah [19]. Kandungan lignin yang tinggi pada serasah Pinus, menyebabkan laju dekomposisi nya menjadi lambat. Hal ini didukung dengan penelitian [20] bahwa kandungan lignin dan selulosa Syzygium javanicum, sebesar $28.09 \%$ dan $28.71 \%$ memiliki peluang untuk terdegradasi lebih cepat dibandingkan dengan Swietenia macrophyla yang memiliki kandungan lignin dan selulosa yang tinggi, yaitu sebesar $52.59 \%$ dan $26.44 \%$. Besarnya kandungan lignin akan menghambat proses dekomposisi karena lignin merupakan senyawa komplek sehingga sulit terurai oleh mikroorganisme tanah [11]. Semakin tinggi kandungan lignin, dekomposisi semakin lambat [21]. Hal ini dikarenakan lignin sangat resisten terhadap degradasi, baik secara biologi, enzimatis, maupun kimia. Karena kandungan karbon yang relatif tinggi dibandingkan dengan selulosa dan hemiselulosa, lignin memiliki kandungan energi yang tinggi.

Berdasarkan uji korelasi Pearson, bahwa faktor curah hujan memiliki nilai korelasi yang mendekati $1(p=0.749)$ dan berkorelasi positif begitupula pada suhu $(p=0.506)$ meskipun tidak signifikan. Sehingga dapat disimpulkan bahwa curah hujan dan suhu memiliki hubungan yang kuat dengan proses laju dekomposisi sersaha, sehingga apabila curah hujan dan suhu meningkat, maka laju dekomposisi serasah juga akan mengalami peningkatan.

\section{KESIMPULAN}

Laju dekomposisi tertinggi terjadi pada periode I dengan kondisi curah hujan yang cenderung tinggi dibandingkan dengan periode II yang curah hujannya cenderung rendah. Berdasarkan uji yang telah dilakukan dapat disimpulkan bahwa laju dekomposisi serasah pada hutan dominan pinus lebih dipengaruhi curah hujan $(p=0.749)$ dibandingkan dengan suhu $(p=0.506)$ dan kandungan lignin.

\section{DAFTAR PUSTAKA}

[1] A. J. Sohng, R. Han, Y. P. M. Jeong, B. B. Park, and P. S. Park, "Seasonal Pattern of Decomposition and N, P, and C Dynamics in Leaf litter in a Mongolian Oak Forest and a Korean Pine Plantation," Forests, vol. $5,2014$.

[2] A. M. O'connel, "Nutrient Dynamic in Decomposing Litter in Karri (Eucalyptus divercolor F. Muell) Forest of South-Western Australia," $J$. Ecol, vol. 76, pp. 1186-1203, 1989.

[3] J. M. Melillo, J. D. Aber, and J.F. Muratore, "Nitrogen and Lignin Control of Hardwood Leaf Litter Decomposition Dynamics," Ecol, vol. 63, no. 3, pp. 621-626, 1989.

[4] S. Hardiwinoto, S. Haryono, M. Fasis, and S. Sambas, "Pengaruh Sifat Kimia Terhadap Tingkat Dekomposisi Beberapa Jenis Tanaman Hutan. Manusia dan Lingkungan," J. Pus. Penelit. Lingkung. Hidup, vol. 4, no. 2, pp. 25-36, 1994.

[5] Q. Liu, S. L. Peng, H. Y. Zhang, Z. A. Li, W. H. Ma, and N. Y. Li, "Decomposition of leaf litter in tropical and subtropical forest of southern China," J. Trop. For. Sci., vol. 17, no. 4, pp. 543-556, 2005.

[6] W. Mudyantini, "Pertumbuhan, Kandungan Selulosa dan Lignin pada Rami (Boehmeria nivea L. Gaudich) dengan Pemberian Asam Giberalat (GA3)," Biodiversitas, vol. 19, no. 4, pp. 269-274, 2008.

[7] M. Ardon, C. M. Pringle, and S. L. Eggert, "Does leaf chemistry differentially affect breakdown in tropical versus temperate streams? 
Importance of standardized analytical techniques to measure leaf chemistry," J. N. Am. Benthol. Soc, vol. 28, no. 2, 2009.

[8] S. V. Sari, I. Qayim, and I. Hilwan, "Litter Decomposition Rate of Karst Ecosystem at Gunung Cibodas, Ciampea Bogor Indonesia," J. Trop. Life Sci., vol. 6, no. 2, pp. 107-112, 2016.

[9] A. T. Austin and P. M. Vitousek, "Precipitation, decomposition and litter decomposability o Metrosideros poymorpha in native forest on Hawai'i," J. Ecol., vol. 88, pp. 129-138, 2000.

[10]N. Sulistinah, "Potensi Melanotus sp. Dalam Mendegradasi Lignin," $J$. Biol., vol. 12, no. 1, pp. 6-8, 2008.

[11]Y. Aprianis, "Produksi Dan Laju Dekomposisi Serasah Acacia crassicarpa A. Cunn. di PT. ARARA ABADI," Tekno Hutan Tanam., vol. 4, no. 1, pp. 41-47, 2011.

[12] Y. Nuraini, "Dekomposisi beberapa tanaman penutupan tanah dan pengaruhnya terhadap siat-siat tanah, serta pertubuhan dan produksi jagung pada utisol Lampung," Institut Teknologi Pertanian Bogor, 1990.

[13] I. Hilwan, "Produksi, Laju Dekomposisi dan Pengaruh Alelopati Serasah Pinus merkusii Jungh, et de Vriese dan Acacia mangium wild di Hutan Gunung Walat, Sukabumi, Jawa barat,” Institut Pertanian Bogor, 1993.

[14]E. V. Salgado, E. M. Andrade, J. N. Hevia, E. P. Nunes, and M. Rodrigues, "Rainfall patterns and the contribution of litter in the caatinga dry tropical forest," Rev. Cienc. Agron., vol. 46, no. 2, pp. 299-309, 2015.
[15]F. L. Dita, "Pendugaan Laju Dekomposisi Serasah Daun Shorea Balangeran (Korth.) Burck Dan Hopea Bancana (Boerl.) Van Slooten Di Hutan Penelitian Dramaga, Bogor, Jawa Barat,' Institut Pertanian Bogor, 2007.

[16]E. Maradhy, "Aplikasi Campuran Kotoran Ternak Dan Sedimen Mangrove Sebagai Aktivator Pada Proses Dekomposisi Limbah Domestik," Universitas Hasanuddin, 2009.

[17]H. H. Siringoringo, "Peranan Penting Pengelolaan Penyerapan Karbon Dalam Tanah,” J. Anal. Kebijak. Kehutan., vol. 11, no. 2, pp. 175 - 1924, 2014.

[18] Y. M. S. Salah and M. C. Scholes, "Eect o Temperature and Litter quality on Decomposition Rate o Pinus Patula needle litter," in Procedia Environmental Science, 2011, pp. 180-193.

[19] M. M. Rahman, J. Tsukamoto, M. M. Rahman, A. Yoneyama, and K. M. Mostafa, "Lignin and Its Effects on Litter Decomposition in Forest Ecosystems," Chem. Ecol., vol. 29, no. 6, pp. 540-553, 2013.

[20]A. P. Fiqa and S. Sofiah, "Pendugaan Laju Dekomposisi dan Produksi Biomassa Serasah Pada Beberapa Lokasi Di Kebun Raya Purwodadi," Pasuruan, 2010.

[21]H. Yulipriyanto, "Laju Dekomposisi Pengomposan Sampah Daun Dalam Sistem Tertutup," in Prosiding Seminar Nasional, 2009. 